\title{
Análise pragmática das respostas de crianças com e sem distúrbio específico de linguagem***
}

Lidiane Cristina Rocha* Débora Maria Befi-Lopes**

\author{
Analyses of answers presented by children with and without specific \\ language impairment
}

*Fonoaudióloga. Mestre em Lingüística e Semiótica Geral pela Faculdade de Filosofia, Letras e Ciências Humanas da Universidade de São Paulo. Fonoaudióloga do Hospital do Servidor Público do Recife - PE. Endereço para correspondência: Rua Leonardo Bezerra Cavalcanti, 790 Apto. 302 - Recife - PE - CEP 52060030 (lidiane@gmail.com).

**Fonoaudióloga. Livre-Docente em Fonoaudiologia pela Faculdade de Medicina da Universidade de São Paulo. Professora Associada do Curso de Fonoaudiologia do Departamento de Fisioterapia, Fonoaudiologia e Terapia Ocupacional da Faculdade de Medicina da Universidade de São Paulo.

***Parte da Dissertação de Mestrado da Primeira Autora Realizada no Departamento de Lingüística Geral da Faculdade de Filosofia Ciências Humanas da Universidade de São Paulo.

Artigo de Pesquisa

Artigo Submetido a Avaliação por Pares

Conflito de Interesse: não

Recebido em 01.12.2005.

Revisado em 05.06.2006; 13.10.2006; 08.11.2006.

Aceito para Publicação em 08.11.2006.

\begin{abstract}
Background: children start to differentiate questions from non-questions and also start to adjust their answers at the age of two. This participation in verbal exchanges requires basic conversational abilities such as the competence to initiate interact and reply appropriately, and to maintain the interaction. Aim: to analyze and correlate the pragmatic aspects of language, related to the type of answers, during an adult/child interaction in children with normal language development and in those diagnosed with Specific Language Impairment (SLI). Method: 16 children with SLI (GP) and ages between three and six years, and 60 children with normal language development (GC) and ages between three to five years - 20 for each age group, 10 of each gender. Data gathering occurred in two different days, with the adult/child interaction being facilitated by toys. Data (speech of child and adult) were transcribed and analyzed, obtaining a Reliability Index of 93.75\%, and later were submitted to statistical analyses. Results: answers were classified in categories and grouped according to the following: Adequate Answers (RA) and Inadequate Answers (RI), always in accordance to the established communicative context. GC presented a significantly higher average of RA when compared to GP, and GP presented a significantly higher average of RI when compared to GC. GC presented a decrease in the use of RI at the increase of age. GP maintained the use of RI at the increase of age, including the age group of six. Conclusion: it was observed that the increase in age emphasized differences between GP and GC. GP presented a less effective communication maintaining unintelligible speech, whereas GC presented more elaborate communication abilities. More studies with older children are necessary for the better understanding of the observed trends.
\end{abstract}

Key Words: Language Disorders; Answer; Language Development.

\section{Resumo}

Tema: a partir dos dois anos de idade a criança passa a diferenciar perguntas de não perguntas e também passa a ajustar suas repostas. Esta participação nas trocas verbais requer habilidades conversacionais básicas, como capacidade para iniciar e interagir e para responder apropriadamente e manter a interação. Objetivo: analisar e correlacionar os aspectos pragmáticos da linguagem, referentes aos tipos de respostas, durante interação adulto/criança, em crianças com desenvolvimento normal de linguagem e naquelas com diagnóstico de Distúrbio Específico de Linguagem (DEL). Método: participaram 16 crianças com DEL (GP) de três a seis anos e 60 crianças em desenvolvimento normal de linguagem (GC) de três a cinco anos, sendo 20 para cada faixa etária, dez por sexo. A coleta de dados aconteceu em dois dias, com díade comunicativa criança/ adulto facilitada por brinquedos. Os dados (fala da criança e do adulto) foram transcritos e analisados e passaram por análise de Índice de Confiança com 93,75\% de concordância, depois foram submetidos à análise estatística. Resultados: as respostas foram classificadas em categorias e agrupadas em Repostas Adequadas (RA) e Repostas Inadequadas (RI), sempre de acordo com o contexto comunicativo estabelecido. O GC apresentou média significativamente maior do que o GP para o uso de RA e o GP apresentou média significativamente maior que o GC para o uso de RI. O GC diminuiu o uso de RI com o aumento da idade. O GP manteve o uso de RI com o aumento da idade, inclusive para a faixa etária de seis anos. Conclusão: foi observado que o aumento da idade salientou as diferenças entre GP e GC. O GP foi menos efetivo na comunicação mantendo ininteligibilidade de fala, ao passo que o GC apresentou habilidades conversacionais mais elaboradas. Porém, novos trabalhos com idades mais avançadas precisam ser realizados para melhor compreensão dessas tendências observadas.

Palavras-Chave: Distúrbio de Linguagem; Resposta; Desenvolvimento de Linguagem.

Referenciar este material como:

1 ROCHA, L. C. ; BEFI-LOPES, D. M. Analyses of answers presented by children with and without specific language impairment (original title: Análise pragmática $\sum 3$ das respostas de crianças com e sem distúrbio específico de linguagem). Pró-Fono Revista de Atualização Científica, Barueri (SP), v. 18, n. 3, p.229-238, set.-dez. 2006 . 


\section{Introduction}

On normal language development, it is possible to observe the blooming of pragmatic abilities. Even before emitting words, the child is capable of answering to social initiatives of others, and, sooner as the first month of life, she demonstrates alternation in the communication. In the beginning this occurs through non verbal forms and the language development improves this interaction, making the child increasingly more active in the communication (Ochs Keenan, 1983; Fernandes, 1997).

As she develops herself, the child acquires and uses more interactive communicational functions that control or drive the behavior of others, this being an inherent social interaction need of the human being, that stimulates the initial linguistic production. She initially manifests its communicative intention with gesture and visual attention, and with the beginning of speech, the pragmatic abilities reveal themselves in a more productive way, through nominations; commentaries; requests of information, objects and attention; answers, protests and greetings (Brinton and Fujiki, 1982; Roth and Spekman, 1984).

Shatz and McCloskey (1984) had placed that beginning from two years of age, the child starts to differentiate questions from non questions and also she starts to adjust her replies, the first acquisitions of answers being those referring to questions with interrogative pro names - "wh" questions. With the beginning of answering abilities, the young children normally present semantic- and pragmatically inappropriate answers. These children use the voice tune as a trigger for answers; therefore this tune serves as track for the answers for questions. For these authors, the increase of the lexicon leads to improvement in the quality of the answers, guaranteeing that, from the three years, the children are capable to present several forms of answers (Shat and Mccloskey, 1984).

On the same subject, Reed (1994) made a research revision and found similar data. After two years, approximately, $40 \%$ of the children keep the topic of the speech in the conversation and, at three years, $50 \%$. However, between three years and a half and four years, the children demonstrate abilities in topic maintenance, carrying through a greater number of commentaries in the speech.

Hadley and Rice (1991), had pointed out that the participation in verbal exchanges requires basic conversational abilities, as the capacity to initiate, interact and to answer appropriately and to keep the interaction. The abilities of verbal interaction are the center of language development theories in the social context. The authors had also cited that during the social interaction, the children learn how to use the language and its social necessities.

However, normal development does not always occur, and it is not rare the sprouting of Alterations in the Development of Language, as the Specific Language Impairment (SLI). The SLI children have heterogeneous symptoms, its criteria being most defined by exclusion, which are: absence of mental disorder, absence of audition loss, absence of mental retardation or severe emotional problems characterizing severe problems of understanding and expression of speech and language (Statk and Tallal, 1981; Rapin, 1996).

Some studies have observed that children with SLI possess limited discursive abilities (Creaghead, 1993), which can cause bad social consequences in the process of social interaction, also intervening with life quality (Hadley and Rice, 1991; Rice et al. 1991; Fujiki et al. 1999; Conti-Ramsden and Botting, 2004; Fujiki et al. 2004; Hart et al. 2004).

Craig and Washington (1993) had observed that children with SLI, in comparison with normal children demonstrate some essential conversational functions, however, in many cases, they express themselves in a less effective way. These children with SLI have greater probability to develop pragmatic problems.

Rice et al. (1991) also had observed unintelligibility in SLI children and the preference for adult interlocutors. This is so because those demonstrate greater availability to understand their incomprehensible message.

However, even though the turn exchanges show these aspects, these children end up answering more that initiating communicative acts. Also, they make more use of non verbal communicative means, what contributes to they demonstrating a more passive communicative behavior than their pairs of same age (Creaghead, 1993; Befi-Lopes et al. 2000).

The answers of children with SLI are an important focus in the study of pragmatics. Comparing pairs of children of same age, with SLI and in normal development of language, the first ones answer inappropriately more time. When compared using the average extension of the statements (MLU), the children with SLI fail in more complex elaborations and in the abilities to structuralize its answers. This means that children with SLI do answer, however in a linguistically atypical form (Craig, 1995). Also Thordardottir and Weismer (2002) had observed lesser use of sophisticated linguistic structures than their peers in this population. 
Befi-Lopes et al. (2001, 2004) had carried through a study with children with SLI (research group - GP) and children in normal development (control group GC) of same age band, from two years of age to four years and 11 months, with the objective to analyze the sequence of questions and answers of the children in the situation of free game with an adult interlocutor. The data had demonstrated that the research group had more Inadequate Answers than their peers in normal development. Other data also observed in the GP had been: lesser occurrence of clarification requests and more use of unintelligible segments in relation to the control group.

All these observed alterations in this population intervene with the social life of these children, as a communication barrier (Fujiki et al. 1999; ContiRamsden and Botting, 2004; Fujiki et al., 2004; Hart et al., 2004).

Verifying the literature data, the objective of this research is to analyze the pragmatic aspects of language, referring to types of Answers, during the adult/child interaction, in children with normal development of language and in those with SLI diagnosis.

The proposal for this was:

1. To analyze the Turn Exchanges, in accordance with Austin (1962), Searle (1962; 1975), Grice (1967), Brinton and Fujiki (1982), Brinton et al. (1986); BefiLopes et al. (2001/2004) as for the types of answers of children in relation to questions of the adult interlocutor.

2. To compare the development of the Research Group in relation with the Control Group in the tested abilities.

\section{Method}

This research was analyzed by the Comissão de Ética para Análise de Projetos de Pesquisa CAPPesq of the Diretoria Clínica of the Hospital das Clínicas and the Colégio de Medicina da Universidade de São Paulo, in the 12.11.02 session, and was approved with the Protocolo de Pesquisa $n^{\circ} 814 / 02$.

Casuistry

The parents of all the children had assented with the participation of the subjects in the research, signing the Term of Free and Clarified Assent.
Two different groups of children had participated of this research, divided in Control Group (GC) and Research Group (GP).

The GC was initially composed by 60 children in normal language development, all pertaining to the Centro Municipal de Educação Infantil (CEMEI) of Campinas/SP. Of these children, 30 were women (50\%) and 30 were man (50\%). This group's age was from 3:0 years to 5:11 years, 20 children, ten of each sex for each one of three age bands (3:0 the $3: 11 ; 4: 04: 11$ and 5:0 the 5:11 years).

The initial criteria for the inclusion of the children of the GC in the research was:

- absence of language disorder complaint for the professor and/or monitor of the group; . absence of former language disorder treatment; - good communicative standard, according to professor and/or monitor.

Based upon above procedures, the indicated children had been grouped by age. Having more than ten subjects of each sex for the same age, the choice was drawing, to guarantee randomness.

All children had been filmed and its data transcribed and analyzed. Calculation of the reliable interval for the communication initiatives were carried through after the transcription and analysis. This criteria was, effectively, what allowed the inclusion or not of the child in the GC. All subjects found below or above of the established reliable interval for each age had been eliminated from the final analysis of the research. Acting so, we believe to have eliminated any bias from professors and/ or monitors in the guiding of children with some alteration. The GC was distributed in agreement with Chart 1.

The GP was composed by 16 children, of those three women (19\%) and 13 men (81\%), all in attendance at the Laboratório de Investigação Fonoaudiológica em Desenvolvimento de Linguagem e suas Alterações, of the Curso de Fonoaudiologia of the FMUSP, with diagnosis of Specific Language Impairment (SLI). The age of the subjects was from 3:0 years to 6:11 years, with variations in the number of subjects for the different age bands, being three girls in the five year band and boys in all age bands.

The criteria of inclusion of the children of the Laboratory for the research was:

1. To have concluded the diagnostic process from the Test of child language in the phonological areas, vocabulary, pragmatic and fluency (Andrade et al. 2000). 
2. To present diagnosis of SLI, or either, absence of mental clutter characterized by severe problems of understanding and expression of speak and language; absence of hearing loss; severe emotional problems (Stark and Tallal, 1981) and still low scores in the test for language evaluation (Rice, 1997).

3. To present age between 3:0 and 6:11 years in the period of collection of the data.

The greater GP age band variation (from 3:0 to 6:11 years) in relation to GCs (3:0 the 5:11 years) was intentionally for making correlations of data possible, and verifying if, in the objectives of this research, the population with SLI presented linguistic behaviors related to inferior ages, referring to pragmatic abilities. The subjects of the GP have a distribution by age band as presented in Chart 2 .

\section{Materials}

The materials used for registering data had been: Video recorders; tape recorders ; compact 30mm VHS tapes; audio K7 tapes of 60 and 90 minutes. Toys: two dolls of the type "Barbie"; two dolls of the type "babies"; two baby's bottles; one little chair; one little pillow; one little purse (with fasteners of hair, two hair rubber bands, two combs, a bottle of perfume, two necklaces); one dismountable doll house with two mini dolls, four trees, a tractor, a fence and four animals (horse, pig, cow, sheep); a truck; a horse wagon without horse; one little oven with two pans and a fryingpan; four plates, six places setting, two cups, two mugs, two ices creams and two sticks to mix juice.

A protocol for the analysis of the data was used also (Attachment 1).

Procedure

The collection of data was carried through during two different days, each child (GC and GP) was filmed two times, each time with 14 minutes of duration. The GC children had been filmed with the researcher as adult interlocutor in the "dollhouse" of the day-care center, for the GP, since the establishment of contact with this population is very difficult, each child was filmed with its respective therapist in the proper therapy room.

The orientation for all recordings was to distribute the toys over the ground and, when seating with the child, inviting her to play with the displayed toys. The adult interlocutors talked normally with the child during the recordings, as requested, without concerning the communicative space used by the adult or the child.

Form of analysis of the data

All children had its activities recorded in audio and video. The speeches of child and adult during the recordings were transcribed and analyzed, and the gestures with communication intentions (yes and no with head rocking, among others) were observed also.

Each subject had 28 minutes of interaction transcribed and analyzed, 14 minutes for each filming. The transcriptions had been carried through using the acronyms A for adult speak and $\mathrm{C}$ for child. Other symbols used in the transcriptions had been the slash (/), being that its use served to indicate the occurrence of interruption of speaks, either the child interrupting the adult or the opposite. Example:

\section{A - Mas nós não vamo/}

C - Tia olha isso daqui.

For the occurrence of Unintelligible Segments (SI), the symbology proposed by Andrade (2000) was adopted, composed by eight til characters ( ). In accordance with the objectives of this research, the data had been analyzed following the proposals of some authors.

1. To analyze the Exchanges of Turn, carried through by research subjects, referring to types of Reply to speak acts of the listener, and these answers had been found in several forms and analyzed according to Brinton and Fujiki, (1982); Befi-Lopes et al. (2001/ 2004). In a first classification, two great groups of answers had been observed, being described by:

1.1. Adequate answers: they had answered correctly to the question of the interlocutor, being subdivided in the following classification:

1.1.1. Adequate Verbal answers (RVA) - when the reply of the child it satisfactory to the adult question and respected the conditions of happiness (Austin, 1962) and the principles of cooperation considered by Grice (1967).

Exemple 1:

A - O que cê tava fazendo de atividade lá na sala? C - Tava escrevendo as palavrinhas e depois eu ia pinta. RVA 
Exemple 2:

A - Cê já viu o carneirinho de verdade?

C - Não. RVA.

1.1.2. Adequate Gestuais answers (RGA) - indicative gesture, representative, related smiles or corporal manifestations to the question.

Exemple:

A - Essa casinha cê sabe monta sozinho?

C - (G não). RGA.

1.1.3. Respostas Vocais (RVO) - onomatopéias e produções orais com 25\% ou menos dos fonemas da língua. Incluem-se aqui nesta categoria as respostas do tipo "tchu-tchu" para não e "hã-hã" para sim.

Exemple 1:

A - Quem?

C - Ei. (ele) RVO.

1.1.4. Contingent answers (RCT) - answers that kept a part of the preceding topic or part of the information contained in previous communicative act.

Exemple:

A - Vão pra onde?

C - Eles vão, sabe pra onde? RCT (repete a emissão anterior ou parte dela, ver sublinhado).

A - Ã?

C - Lá lonjão. RCT (repeat previous emission or part, as underlined).

1.2. Inadequate Answers: the adult interlocutor had understood the answers emitted by the children but had not been satisfied by it. They had also been divided in the categories below:

1.2.1 To Ignore the Interlocutor (Ig) - to do not present any type of reply.

Exemple:

A - O que vocês vieram fazer aqui, hein?

C - (sem resposta). Ig.

1.2.2. Maintenance of Previous Topic (TA) - when the child kept the previous subject, without demonstrating apparent recognition of the question from the interlocutor.
Exemple:

$A$ and $C$ talks verifying if the truck entered in the house, and A speak about making a house and the child agreed, after that she asked:

A - Como será que a gente pode fazer, hein?

C - Uma casona. RVA

A - Uma casona?

C - Uia, num cabe (sobre o caminhão). TA.

1.2.3. Inadequate Reply (Ri) - when the information supplied for the child was not enough for the listener to identify objects of the topic of the speech (Ochs-Keenan and Schieffeling, 1983), or still, when the child did not respect the conditions of happiness and value of truth, thus carrying through an inadequate reply to the communicative context (Austin, 1962).

Exemple 1:

A - O que tem aí?

C - Hum, isso aqui é... e esse e esse. Ri.

Exemplo 2:

A - Que horas você deu a mamadeira?

C - Amanhã. Ri.

1.2.4. Answer with Unintelligible Segments (RSI) Incomprehensible productions.

Exemplo:

A - A fica assim, e a porta fica aberta?

C - RSI.

1.2.5. Inadequate Gestual Answer (RGI) - May be an indicative act, representative, smiles or others corporal manifestations with no relation to the question.

Exemple:

A - Aonde você comprou esse sorvete?

$\mathrm{C}$ - Na vaderia. $\mathrm{Ri}$

A - Na lavanderia?

C - (G sim). RGI.

Defined the analysis criteria, a sample of the data of the GC was submitted to a fidelity judgment. Six subjects, one of each sex for each age band had been drafted. The female judge, a post-grad speak pathologist student, evaluated them from the stipulated criteria and the gotten reliability Index was of $93.75 \%$. 
CHART 1. Distribution of GC subjects.

\begin{tabular}{|c|c|c|c|}
\hline Control Group & Women & Men & Total \\
\hline GC1 from 3:0 to 3:11 years of age & 6 & 4 & 10 \\
\hline GC2 from 4:0 to 4:11 years of age & 5 & 6 & 11 \\
\hline GC3 from 5:0 to 5:11 years of age & 4 & 5 & 9 \\
\hline Total & $\mathbf{1 5}$ & $\mathbf{1 5}$ & $\mathbf{3 0}$ \\
\hline
\end{tabular}

CHART 2.4 Distribution of GP subjects.

\begin{tabular}{|c|c|c|c|}
\hline Research Group & Women & Men & Total \\
\hline GP1 from 3:0 to 3:11 years of age & 0 & 2 & 2 \\
\hline GP2 from 4:0 to 4:11 years of age & 0 & 4 & 4 \\
\hline GP3 from 5:0 to 5:11 years of age & 3 & 2 & 5 \\
\hline GP4 from 6:0 to 6:11 years of age & 0 & 5 & 5 \\
\hline Total & $\mathbf{3}$ & $\mathbf{1 3}$ & $\mathbf{1 6}$ \\
\hline
\end{tabular}

\section{Results}

The data was submitted to statistical treatment, with $\mathrm{p} \quad 0.05$ being adopted as the value of significance.

The averages obtained in each one of the categories of answers are below.

Verifying the last columns of Table 1, the data shows that the GP presented minor average of RA and greater average of RI in relation to the GC, what can also be observed in Figure 1.

With this Figure 1 it is possible to notice an accented decrease in the use of RA and RI in GC. But this tendency is not apparent in GP. To analyze this decrease in the use of RA the data is analyzed in Table 2.

The data confirmed a significant decrease in the use of RA in the sub-groups of GC (value $\mathrm{p}=0,05$ ). For the GP was confirmed that this behavior was not verified, since value $p$ was high ( $p=0,25>0,05$ ).

A Regression Analysis was carried through on the data and the trends for each group were verified, as Figure 2 shows.

This figure illustrated the decrease in RA usage for both groups, but with greater slope in GC, indicating a greater decrease in this group tied with the increase of age.

Figure 3 presents the usage frequency of each RA category for all studied sub-groups.

Both GC and GP sub-groups, have a similar usage of RA categories, however, the GP used more the RVO (vocal communicative medium) category than the GC.
Analyzing the RI, the table below presents the analysis of decrease for the use of these answers for the two studied big groups (GC and GP).

With this t test, significant evidences of RI usage reduction with increasing age had not been found. The p values had been above the level of significance either for the GP and GC. These data were submitted to a Regression Analysis. From this calculation it was possible to identify different trends in RI usage for GP and GC, as presented in Figure 4.

The GC presented a negative inclination, indicating that, concomitant to age increase, it had a reduction in the use of RI. Nevertheless, GP presented a more linear trend, disclosing that, for these children, it had maintenance in the use of RI even with the age increase, this maintenance is also observed for the six years old age band.

In relation to RI categories, Figure 5 presents more information.

These data revealed that the GC sub-groups had carried through less replies of this type than the GP. Generally, the more used categories had been Ig, Ri and TA respectively. On the other hand, the GP carried through more Ig, Ri, RSI, TA and RGI respectively. The RSI category, that evidences unintelligibility, was not observed in any age studied in the GC, while GP used it, even in the six years old age band.

Even with the differences observed between GP and GC throughout the analyses, some GP 
subjects with averages next to the ones in the GC; and the opposite; were detected. This represented an alert for the exclusively quantitative approach.

TABLE 1. Answer types data for GP and GC.

\begin{tabular}{|c|c|c|c|c|c|c|c|c|c|c|c|}
\hline \multirow{3}{*}{ SUBGROUPS } & \multicolumn{9}{|c|}{ TURN EXCHANGE } & \multirow{3}{*}{ RA } & \multirow{3}{*}{ RI } \\
\hline & \multicolumn{4}{|c|}{ Adequate Answers } & \multicolumn{5}{|c|}{ Inadequate Answers } & & \\
\hline & RVA & RGA & RVO & RCT & Ig & TA & $\mathrm{Ri}$ & RSI & RGI & & \\
\hline GP & 45,02 & 22,62 & 2,86 & 0,06 & 8,68 & 1,21 & 4,76 & 1,61 & 1,48 & 72,12 & 17,6 \\
\hline GC & 71,93 & 25,83 & 1,34 & 0,41 & 6,08 & 1,41 & 2,73 & 0 & 0,26 & 101,5 & 11,98 \\
\hline
\end{tabular}

Legend: RVA: Adequate Verbal answers; RGA: Adequate Gestual answers; RVO: Vocal Answer; RCT: Contingent Answer; Ig: To Ignore the Interlocutor; TA: Maintenance of Previous Topic; RSI: Answer with Unintelligible Segments; Ri: Incorrect Answer; RGI: Inadequate Gestual Answer; RA = RVA+RGA+RVO+RCT; RI = Ig+TA+Ri+RSI+RGI.

FIGURE 1: RA and RI average for the GC and GP subgroups

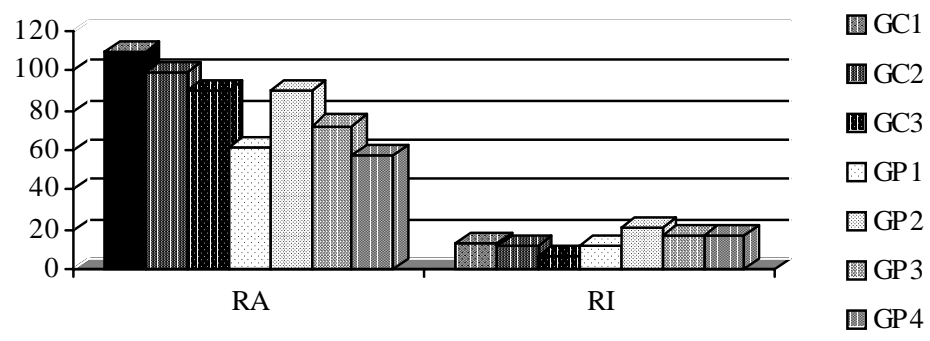

TABLE 2. T-Student test for variable RA to subgroups of GC and GP

\begin{tabular}{|c|c|c|c|c|c|c|}
\hline Variável & $\mathrm{H}_{0}$ & HÁ & $\mathrm{t}$ & $\mathrm{p}$ & $\mathrm{Gl}$ & Decisão \\
\hline RA & $\begin{array}{c}\text { Médias dos } \\
\text { subgrupos do GC } \\
\text { decrescem com a } \\
\text { idade }\end{array}$ & $\begin{array}{c}\text { Médias } \\
\text { permanec } \\
\text { em iguais }\end{array}$ & $-2,0$ & $\mathbf{0 , 0 5}$ & 1 & $\begin{array}{c}\text { Não } \\
\text { rejeita } \\
\mathrm{H}_{0}\end{array}$ \\
\hline RA & $\begin{array}{c}\text { Médias dos } \\
\text { subgrupos do GP } \\
\text { decrescem com a } \\
\text { idade }\end{array}$ & $\begin{array}{c}\text { Médias } \\
\text { permanec } \\
\text { em iguais }\end{array}$ & $\begin{array}{c}- \\
1,15\end{array}$ & 0,25 & 1 & $\begin{array}{c}\text { Rejeita a } \\
\mathrm{H}_{0}\end{array}$ \\
\hline
\end{tabular}

Description: RA = RVA+RGA+RVO+RCT; H0: Null Hypothesis; HA:

Alternative Hypothesis; t: test statistical value; $p$ : significance value( $\mathrm{p}$ value); gl: degree of freedom.

FIGURE 2: RA usage versus age for GC and GP.

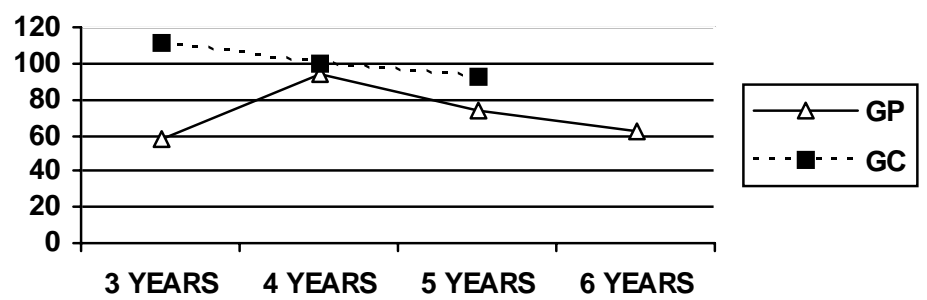


TABLE 3. T-Student test with variable RI for GC and GP subgroups.

\begin{tabular}{|c|c|c|c|c|c|c|}
\hline Variable & $\mathrm{H}_{0}$ & $\mathrm{H}_{\mathrm{A}}$ & $\mathrm{t}$ & $\mathrm{p}$ & gl & Decision \\
\hline RI & $\begin{array}{c}\text { GC } \\
\text { subgroups } \\
\text { means } \\
\text { decrease } \\
\text { with age }\end{array}$ & $\begin{array}{c}\text { Means do } \\
\text { not } \\
\text { change }\end{array}$ & $-0,72$ & 0,476 & 1 & $\begin{array}{l}\text { Do not } \\
\text { rejects } \\
\mathrm{H}_{0}\end{array}$ \\
\hline RI & $\begin{array}{c}\text { GP } \\
\text { subgroups } \\
\text { means } \\
\text { decrease } \\
\text { with age }\end{array}$ & $\begin{array}{l}\text { Means do } \\
\text { not } \\
\text { change }\end{array}$ & $-1,83$ & 0,074 & 1 & $\begin{array}{c}\text { Rejects } \\
\mathrm{H}_{0}\end{array}$ \\
\hline
\end{tabular}

Legend: RI: Inadequate answers (sum of: Ig, TA, Ri, RGI); H0: Null hypothesis; HA: Alternative Hipothesis; t: test stathistical value; $p$ : significance value(p value); gl: degree of freedom.

FIGURE 3. RA categories for GC and GP subgroups

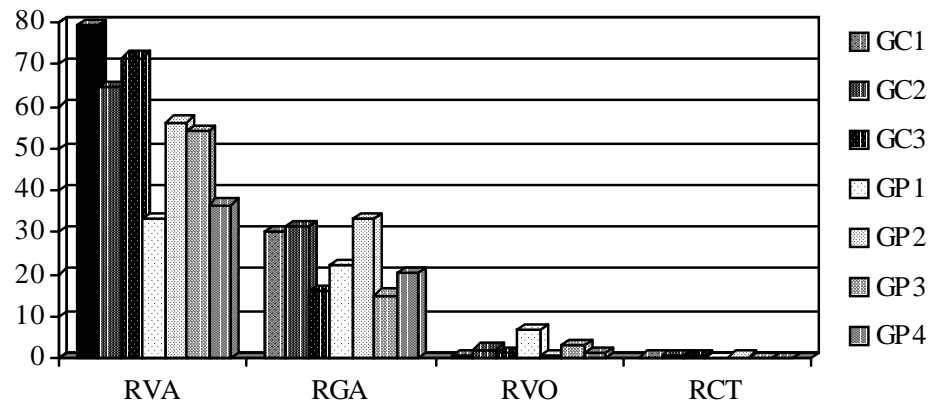

Legenda: RVA: resposta verbal adequada; RGA: resposta gestual adequada; RVO: resposta vocal; RCT: resposta contingente; GC: grupo controle; GP: grupo pesquisa.

FIGURE 4. RI usage versus age for GC and GP.

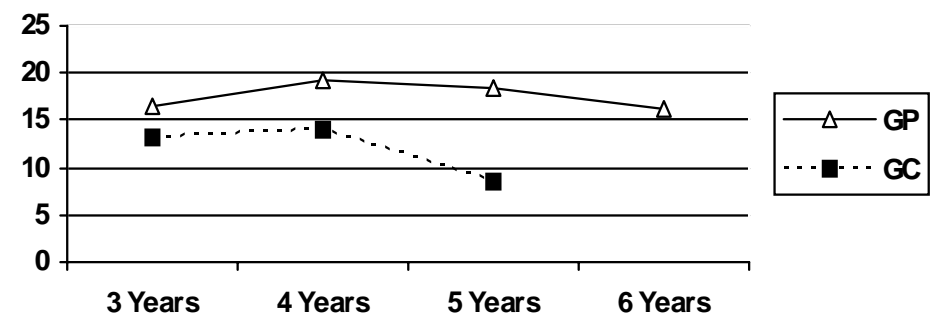

FIGURE 5. RI categories for GC and GP subgroups.

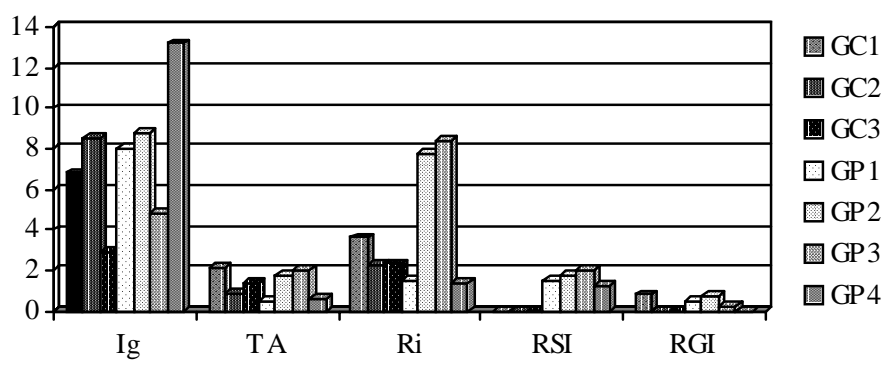

Legenda: Ig = ignorar interlocutor; $\mathrm{TA}$ = manutenção do tópico anterior; $\mathrm{Ri}=$ resposta inadequada; RSI = resposta com segmentos ininteligíveis; RGI = resposta gestual inadequada. 


\section{Discussion}

In the analysis of GP versus GC, the differences of RA and RI averages between sub-groups had not been statistically significant; however, the data Regression Analysis made possible to identify different trends for each one of the groups in relation to RA and RI usage. For RA the GC presented greater averages than GP. The GC also presented a greater trend of average decrease related to age increase than GP.

With the Regression Analysis for RA usage (Figure 2), the decrease trend was identified for GC

observed that the children with SLI, when compared with their peers in normal development, had not presented evident pragmatic alterations, however had demonstrated less use of sophisticated linguistic structures as observed in this research.

Beyond GC having presented more use of RA in relation to GP, the use of the different types of categories in these answers also varied. Normally, both groups had presented greater averages for categories RVA, RGA, RVO and RCT respectively. However, GP presented greater use of categories RGA and RVO in relation to GC, indicating a preference for the use of communicative media other than verbal, as also observed in literature (Creaghead, 1993; Befi-Lopes et al. 2000, Thordardottir and Weismer, 2002). RCT was the least used category by both groups; however, its frequency was higher in GC. In this group the three studied age bands had carried through this type of reply while this category appeared only in the age band of four years in the GP. Since the answers of type RCT demonstrate greater linguistic sophistication, its limited use in GP indicated again the linguistic limitation of these children in relation to its peers.

\section{Conclusion}

Generally speaking, the children with SLI behaved in a pragmatically less effective way than their peers. Those had more initiatives, however, not elaborate as the others, and mainly presenting less Adequate Answers and more Inadequate Answers. only. This data indicated that GC children had started to be more active in the communication in more advanced ages, and this intervened with the number of questions made by the interlocutor. This data have relation with findings of other authors (Brinton and Fujiki, 1982; Roth and Spekman, 1984) that identified the use of more interactive communicative functions with the increase of age in their research, observed mainly for the use of commentaries.

On the other hand, the GP did not demonstrate the same evolution related for the GC. Also it is in accordance with the findings of Craig (1995) and Thordardottir and Weismer (2002), which had possible to establish a period of delay of the GP in relation to GC. The children with SLI behaved in a specific way in relation to the analyzed abilities.

For RI, the GP presented greater averages than GC. Verifying each group, the GC presented a trend of decrease with age increase and GP presented a constant, indicating maintenance of the use RI even for five and six years of age.

Observing specifically RI, from Figure 3 data, GP has a distinct behavior than GC for presenting RI more frequently, even for five and six years of age. GC is characterized specifically for presenting a decline in the Ig category use, tied with age increase, and for not presenting the category RSI. The categories the GC most used had been Ri, TA and RGI respectively. The GP presented a constant use of category Ig and carried through the remaining categories in the following sequence: Ri, RSI, TA and RGI. These data agree with literature when evidencing that children with SLI have a tendency of ignoring the interlocutor in the communicative situation more than their peers in normal development (Brinton and Fujiki, 1982; Hadley and Rice, 1991; Befi-Lopes et al., 2001/2004).

The high use of RI in the GP caused conversational breakings causing to functional problems of language thus disclosing a pragmatic fragility of this group not found in the GC, fact also found in literature (Craig, 1995).

When observing the five years of age (GP and GC) and six years of age (only GP) subgroups, the differences between the groups had been very evident, demonstrating, by that, that the SLI picture is clearer beginning from five years of age. So, when verifying language pragmatic aspects, it was not 
However, more than the acquisition deficit correlation between the groups, some kind of plateau in the development was verified in the GP that beginning with the age of five years.

The data had indicated that the children with SLI had behaved in an increasingly distinct way in relation to their peers with the increase of age. The children of GP had demonstrated communicative limitations marked by unintelligible speak. On the other hand, the children of the GC had demonstrated a communicative evolution by the use more elaborated speak acts. However, new works with more advanced ages and bigger samples of subjects also becomes necessary for better understanding the trends identified in this research.

\section{References}

ANDRADE, C. R. F. Fluência. In: ANDRADE, C. R. F.; BEFI-LOPES, D. M.; FERNANDES, F. D. M.; WERTZNER, H. F. ABFW: teste de linguagem infantil nas áreas de fonologia, vocabulário, fluência e pragmática. Carapicuiba (SP): Pró-Fono, 2000. cap. 3.

AUSTIN, J. L. Quando dizer é fazer: palavras e ação. Tradução de Danilo Marcondes de Souza Filho. Porto Alegre: Artes Médica, 1990. Tradução de: How to do things with words (1962).

BEFI-LOPES, D. M.; CATTONI, D. M.; ALMEIDA, R. C. de. Avaliação de aspectos da pragmática em crianças com alteração no desenvolvimento da linguagem. Pró-Fono $R$. Atual. Cient., Barueri (SP), v. 12, n. 2, p. 39-47, 2000.

BEFI-LOPES, D. M.; RODRIGUES, A.; ROCHA, L. C. Habilidades lingüístico-pragmáticas nas alterações de desenvolvimento de linguagem. In: CONGRESSO BRASILEIRO DE FONOAUDIOLOGIA, 9., 2001, Guarapari (ES). Resumo de anais. Guarapari ES: [s. n.], 2001.

BEFI-LOPES, D. M.; RODRIGUES, A.; ROCHA, L. C. Habilidades lingüístico-pragmáticas em crianças normais e com alterações de desenvolvimento de linguagem. PróFono R. Atual. Cient., Barueri (SP), v. 16, n. 1, p. 57-66, jan.-abr. 2004.

BRINTON, B.; FUJIKI, M. A comparison of requestresponse sequences in the discourse of normal and language-disordered children. J. Speech Hear. Dis., v. 47, p. 57-62, feb. 1982

CONTI-RAMSDEN, G.; BOTTING, N. Social difficulties and victimization in children with SLI at 11 years of age. J. Speech Lang. Hear. Res., v. 47, n. 1, p. 145-161, feb. 2004.

CRAIG, H. Pragmatic Impairments. In: FLETCHER, P.; MacWHINNEY, B. (Ed.). The handbook of child language. Oxford: Basil Blackwell, 1995. cap. 23. p. 622640.

CRAIG, H. K.; WASHINGTON. Access behaviors of children with specific language impairment. J. Speech Hear. Res., v. 36, p. 322-337, apr. 1993.

CREAGHEAD, N. Children with disorders of pragmatics. In: OCHS-KEENAN, E.; SCHIEFFEUN, B. Acquiring conversational competence. London: Routhedge \& Kenan Paul, 1993. p. 105-133.
FERNANDES, F. D. M. Os atrasos de aquisição de linguagem. In: FERNANDES, F. D. M. Fundamentos em Fonoaudiologia. Rio de Janeiro: Guanabara Koogan, 1997. cap. 3, p. 23-37.

FUJIKI, M.; BRINTON, B.; HART, C. H.; FITZGERALD, A. H. Peer acceptance and friendship in children with specific language impairment. In: GALLAGHER, T. M. (Ed.). Topics in language disorders. [S.l.]: Aspen publishers Inc, 1999. v. 19, n. 2, p. 34-48. feb. 1999.

FUJIKI, M.; SPACKMAN, M. P.; BRINTON, B.; HALL, A. The relationship of language and emotion regulation skills to reticence in children with specific language. J. Speech Lang. Hear. Res.,; v. 47, n. 3, p. 637-646, jun. 2004.

GRICE, H. P. Lógica e Conversação. Tradução de Geraldi, J. W. do original: Logic and Conversation (1967). In: DASCAL, M. (Org.). Fundamentos Metodológicos da Lingüística, 5: pragmática - problemas, críticas, perspectivas da lingüística - bibliografia . Campinas: Unicamp, 1982. p. 81-103.

HADLEY, P. A.; RICE, M. L. Conversational responsiveness of speech and language impaired preschoolers. J. Speech Hear. Res., v. 34, p. 1304-1317, dec. 1991.

HART, K. I.; FUJIKI, M.; BRINTON, B.; HART, C. H. The relationship between social behavior and severity of language impairment. J. Speech Lang. Hear. Res., v. 47, n. 3, p. 647-662, jun. 2004.

OCHS-KEENAN, E. Conversational competence in children. In: OCHS-KEENAN, E.; SCHIEFFELIN, B. Acquiring conversational competence. London: Routledge \& Kegan Paul, 1983. cap. 1, p. 3-25.

OCHS-KEENAN, E.; SCHIEFFELIN, B. Topic as a discourse notion: a study of topic in the conversations of children and adults. In: OCHS-KEENAN, E.; SCHIEFFELIN, B. Acquiring conversational competence. London: Routledge \& Kegan Paul, 1983. cap. 6, p. 114-126.

RAPIN, I. Practitioner review: developmental language disorders - a clinical update. J. Child Psychol. Psychiat., v. 37, n. 6, p. 643-655, sep. 1996.

REED, V. A review of normal language development. In: REED, V. An introduction to children with language disorders. 2. ed. Sidney: The university of Sidney, 1994. cap. 3, p. 61-91. 
RICE, M. L.; SELL, M. A.; HADLEY, P. A. Social interactions of speech - and language - impairment children. J. Speech Hear. Res., v. 34, p. 1299-1307, dec. 1991.

ROTH, F. P.; SPEKMAN, N. J. Assessing the pragmatic abilities of children, part 1: organizational framework and assessment parameters. J. Speech Hear. Dis., v. 49, p. 2-11, feb. 1984.

SEARLE, J. R. Indirect speech acts. In: Cole, P.; Morgan (Ed.). Syntax and semantics, 3.: speech acts. New York: Academic Press, 1975.

SEARLE, J. R. Speech acts: an essay in the philosophy of language. Cambridge: University Press, 1969.
SHATZ, M.; McCLOSKEY, L. Answering appropriately: a developmental perspective on conversational knowledge. In: KUCZAJ, S. A. I. (Ed.). Discourse development: progress in cognitive development research. Springer: New York, 1984. cap. 2, p. 19-36.

STARK, R. E.; TALLAL, P. Selection of children with specific language deficits. J. Speech Hear. Dis., v. 46, p. 114-122, may 1981.

THORDARDOTTIR, E. T.; WEISMER, S. E. Verb argument structure weakness in specific language impairment in relation to age and utterance length. Clin. Ling. Phon., v. 16, n. 4, p. 233-250, jun. 2002. 